Editorial

OOpen Access

CrossMark

\title{
Do biopsies reveal evidence of prevention of pedal melanoma with footwear in a developing community?
}

\begin{abstract}
Early publication on melanoma among the Igbos of Nigeria in the 1970s suggested that shoe wearing will lessen the occurrence of pedal melanoma. Therefore, this study has set out to examine the 1980s and 1990s biopsy series in order to discover any positive change. Surprisingly, in terms of the total cases and the male/sex comparison, there is no evidence of decrease in incidence.
\end{abstract}

Keywords: melanoma, sole, incidence, footwear, no progress
Volume 7 Issue 5 - 2017

\section{Wilson Onuigbo}

Department of Pathology, Medical Foundation and Clinic, Nigeria

Correspondence: Wilson Onuigbo, Department of Pathology, Medical Foundation and Clinic, 8 Nsukka Lane, Enugu 40000I, Nigeria, Tel 2.35E+12, Email wilson.onuigbo@gmail.com

Received: December 21, 2016 | Published: March 03, 2017

\section{Introduction}

In 1975, the author examined at a Regional Reference Laboratory established by the Eastern Nigerian Government at the capital, Enugu, the biopsies received from February 1970 to July 1974 inclusive, totaling approximately 5,000 biopsies. ${ }^{1}$ Of this number, 21 cases of malignant melanoma were obtained. As the site of predilection was the sole of the foot, it was hypothesized that the role of the hot soils and stones of Africa in the bare foot should be considered. ${ }^{2}$ Accordingly, the series covering the 1980s and 1990s were examined to see whether there was any positive trend.

\section{Investigation}

The records kept by the author were searched with reference to the 1980s and 1990s as regards age and sex parameters (Table 1).

Table I Epidemiological data on sex and age

\begin{tabular}{llllll}
\hline $\begin{array}{l}\text { Age } \\
\text { groups }\end{array}$ & 1980s & & 1990s & & Totals \\
\hline & M & F & M & F & 6 \\
$<40$ & 3 & I & I & I & 12 \\
$41-50$ & 3 & 4 & 2 & 3 & 36 \\
$51-60$ & 9 & 9 & 13 & 5 & 26 \\
$61-70$ & 7 & 8 & 5 & 6 & 5 \\
$71+$ & I & - & I & 3 & 85 \\
Totals & 23 & 22 & 22 & 18 & 85 \\
& 45 & & 40 & & 85 \\
\hline
\end{tabular}

\section{Results \& discussion}

The expectation was that fewer cases would be recorded with the years. However, there is no significant difference. In other words, this method shows no evidence of prevention during the two periods recorded. Perhaps, there may be another way of determining matters.

\section{Funding}

None.

\section{Acknowledgements}

None.

\section{Conflicts of interests}

The authors declare that there is no conflict of interest.

\section{References}

1. Onuigbo WIB. Malignant melanomas in the Igbos of Nigeria. Br J Plast Surg. 1975;28(2):114-117.

2. Davies JNP, Tank R, Meter R, et al. Cancer of the integumentary tissues in Uganda Africans. J Natl Cancer Inst. 1968;41(1):31. 